\author{
Supporting Information
}

\title{
Optoelectronic Properties of High Triplet $\sigma-\pi$-Conjugated Poly[(biphenyl group IV-A-atom (C, Si, Ge, Sn)] Backbones
}

Miao-Ken Hung, Kuen-Wei Tsai, Sunil Sharma, Jian Lei, Jun-Yi Wu, and Show-An Chen*

Department of Chemical Engineering, National Tsing-Hua University, Hsinchu 30013, Taiwan

*Email: sachen@.che.nthu.edu.tw.

\section{S1. Measurements and Physical Properties}
A. General measurement and characterization
B. Phosphorescence measurement
C. Electrochemical Study
D. Exciton lifetime measurement
E. Device fabrication
F. Physical and optoelectronic characteristics for the polymers with different central atoms

\section{S2. Materials and Methods}




\section{S1. Measurements and Physical Properties}

\section{A. General measurement and characterization}

${ }^{1} \mathrm{H} \quad$ NMR spectra were recorded using VARIAN UNITYINOVA 500 NMR. Ultraviolet-visible (UV-Vis) spectra and photoluminescent (PL), photoexcitation (PLE) and electroluminescence (EL) spectra were measured using an UV-Vis spectrometer (Perkin-Elmer, Lambda 35) and a fluorescence spectrometer (Jobin Yvon Horiba, Fluoromax-3), respectively. The thicknesses of solid films were measured by a Tencor P-10 Surface Profiler. Gel permeation chromatography (from Waters) assembled with a UV detector and three columns in series (Styragel HR2 4 from Waters) was used to measure molecular weight distributions relative to polystyrene standards at $40{ }^{\circ} \mathrm{C}$.

\section{B. Phosphorescence measurement}

The triplet energies of the polymers are determined by taking the onset values of the phosphorescence spectra from their solid films by using delayed phosphorescence measurement. ${ }^{1}$ The solid film samples were dropped cast from the solutions of $\mathrm{P}(\mathrm{dBPh}-\mathrm{C})$, $\mathrm{P}(\mathrm{dBPh}-\mathrm{Si}), \mathrm{P}(\mathrm{dBPh}-\mathrm{Ge})$ and $\mathrm{P}(\mathrm{dBPh}-\mathrm{Sn})$ in chlorobenzene $(10 \mathrm{mg} / \mathrm{ml})$, and attached to the plain sample holder in a nitrogen cryostat (JANIS ST-100 Optical Cryostat). The samples were excited at $300 \mathrm{~nm}$ by $150 \mathrm{fs}$ pulsed Ti:sapphire laser (Spectra-Physics Hurricane) at 10 $\mathrm{Hz}$ repetition rate in conjunction with an ultrafast optical parametric amplifier (Quantronix TOPAS). The luminescence from the solution was allowed to pass through a monochromator (Princeton Instruments Acton SpectraPro 2300i) and then to a gated intensified CCD camera (Princeton Instruments PIMAX). The detection window of $20 \mathrm{~ms}$ width of the intensified CCD was operated synchronously but delayed by $1 \mathrm{~ms}$ with respect to the laser pulse. To increase the signal to noise ratio, each final spectrum was obtained by averaging the accumulated spectra obtained from 100 pulses. The laser intensity was about $7 \mu \mathrm{J} /$ pulse. All measurements were carried out in a cryostat at $77 \mathrm{~K}$ and under a dynamic vacuum of $10^{-5}$ Torr. 


\section{Electrochemical Study}

All measurements were carried out at room temperature with a conventional three-electrode configuration consisting of the polymer film on platinum $(\mathrm{Pt})$ plate as working electrode, $\mathrm{Pt}$ plate as counter electrode, and a nan-aqueous $\mathrm{Ag} / \mathrm{AgNO}_{3}(0.01 \mathrm{M}$ in acetonitrile $)$ as reference electrode. In all experiment, the $0.1 \mathrm{M} n-\mathrm{Bu}_{4} \mathrm{NPF}_{6}$ in acetonitrile used as the supporting electrolyte and the ferrocene/ferrocenium $\left(\mathrm{Fc} / \mathrm{Fc}^{+}\right)$couple served as internal standard, and the cyclic voltammogram (CV) were observed at scan rates of 25,50 and $100 \mathrm{mV} / \mathrm{s}$, respectively. According to Leeuw et $\mathrm{al}^{2}{ }^{2}$ the ionization potential $\left(\mathrm{E}_{\mathrm{HOMO}}\right)$ of a polymer is approximately equal to the onset oxidation potential relative to that of $\mathrm{Fc}^{+} / \mathrm{Fc}$ plus $4.8 \mathrm{eV}$ (the $\mathrm{Fc}^{+} / \mathrm{Fc}$ energy level below the vacuum level), which means that $\mathrm{E}_{\text {Hомо }}$ can be calculated using $\mathrm{E}_{\mathrm{HOMO}}[\mathrm{eV}]$ $=\mathrm{E}_{\text {onset }}+4.8 \mathrm{eV}$. The energy level of LUMO was deduced from the onset of UV-vis spectrum (band gap) and that of HOMO, which means that $\mathrm{E}_{\mathrm{LUMO}}[\mathrm{eV}]=\mathrm{E}_{\mathrm{HOMO}}+$ band gap.

\section{Exciton lifetime measurement}

All measurements were carried out in a cryostat at room temperature and under a dynamic vacuum of $10^{-6}$ Torr. The solid film samples with or without $12 \mathrm{wt} \%$ FIrpic doped in polymer were excited at $350 \mathrm{~nm}$ using a $150 \mathrm{fs}$ pulsed Ti:sapphire laser (Spectra-Physics Hurricane) as the light source at repetition rate of $1 \mathrm{kHz}$. The lifetime was measured using a 1024-channel time-correlated single photon counting (TCSPC) system with a microchannel plate photomultiplier tube (Hamamatsu Photonics R3809U-50) and a spectrometer (Edinburgh, Lifespec-ps with TCC900 data acquisition card). Time-to-amplitude converter (TAC) range is $5 \mu \mathrm{s}$ for $12 \mathrm{wt} \%$ FIrpic doped in the polymer films. Monitored wavelengths were at the emission maxima for the polymer films and at $470 \mathrm{~nm}$ for $12 \mathrm{wt} \%$ FIrpic doped in the polymer films. The predetermined number of counts for each collection of emission lifetime was set for 5000 counts and emission lifetimes were obtained by exponential tail fit of the emission decay curves. 


\section{E. Device fabrication}

An indium tin oxide (ITO) glass substrate was exposed to oxygen plasma at a power of $50 \mathrm{~W}$ and a pressure of $200 \mathrm{mTorr}$ for $5 \mathrm{~min}$. A thin layer $(30 \mathrm{~nm})$ of poly(styrenesulfonic acid)-doped poly(ethylenedioxythiophene) - the mixture of CLEVIOS ${ }^{\mathrm{TM}}$ P VP AI 4083 and CLEVIOS $^{\text {TM }}$ P VP CH 8000 (2:1 in volume ratio), was spin-coated on the treated ITO as a hole injection layer. All the polymers with $12 \mathrm{wt} \%$ FIrpic or $8 \mathrm{wt} \%$ DMAC-TRZ as the sky-blue emission dopant were dissolved in chlorobenzene $(10 \mathrm{mg} / \mathrm{ml})$ to obtain the emitting layer (EML) solutions, and then spin-coated on top of the PEDOT:PSS layer (30nm). The 1,3,5-Tri(diphenylphosphoryl-phen-3-yl) benzene (TP3PO) layer $(3 \mathrm{~nm})$ and 1,3,5-Tri(m-pyridin-3-ylphenyl)benzene (TmPyPB) layer $(52 \mathrm{~nm})$ were used as a high triplet exciton blocker and a hole blocking/electron transport layer, respectively, which were deposited on top of the EML layer by thermal evaporation in a vacuum of $2 \times 10^{-6}$ Torr. Finally, a thin layer of CsF (about $1 \mathrm{~nm}$ ) covered with aluminum $(100 \mathrm{~nm}$ ) was deposited in a vacuum thermal evaporator through a shadow mask at a vacuum of $2 \times 10^{-6}$ Torr. The active area of device was about $4 \mathrm{~mm}^{2}$. I-V characteristics of the devices were measured using a KEITHEY-238 source meter and brightness measured with a TOPCON BM-8 luminance meter. 
F. Physical and optoelectronic characteristics for the polymers with different central atoms

1. Density functional theory (DFT) calculation

(b) $\mathrm{d}(\mathrm{MeOPh}-\mathrm{C})$

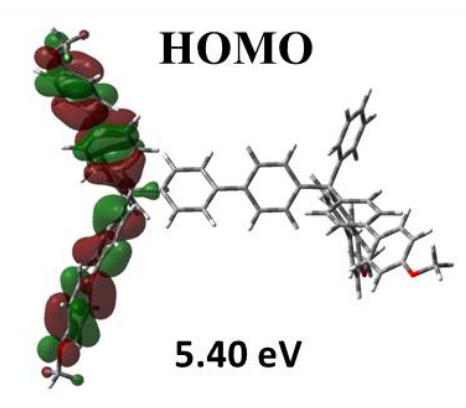

(c) d(MeOPh-Si)

(a)

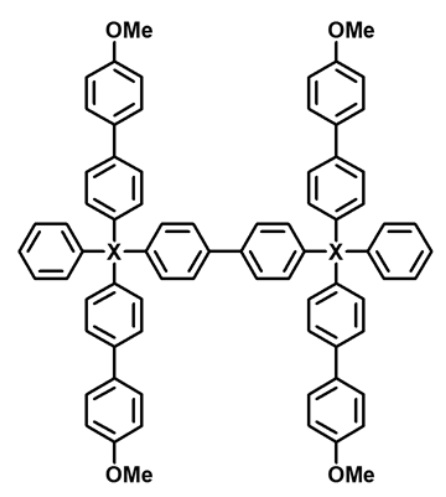

$\mathrm{X}=\mathrm{C}, \mathrm{Si}, \mathrm{Ge}$, and Sn

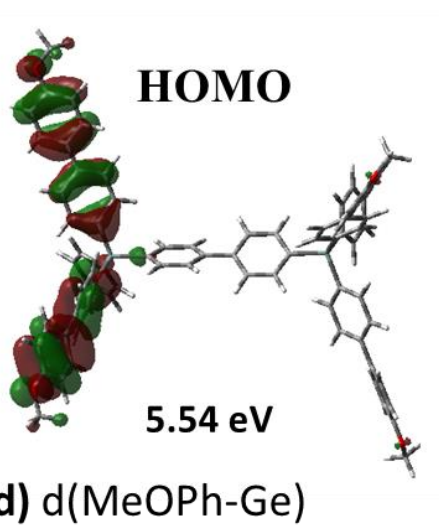

(d) d(MeOPh-Ge)

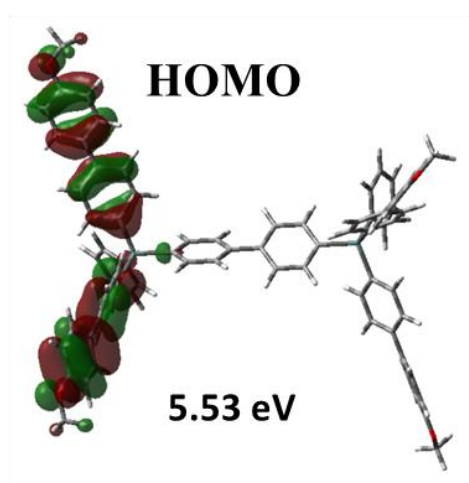

(e) d(MeOPh-Sn)

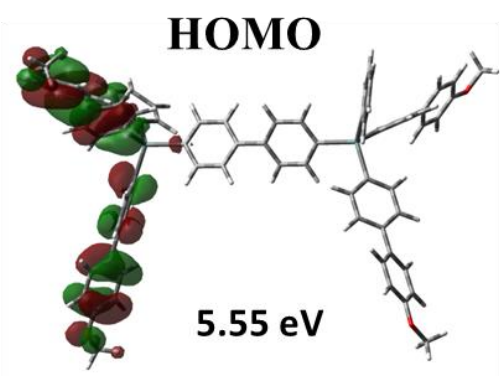

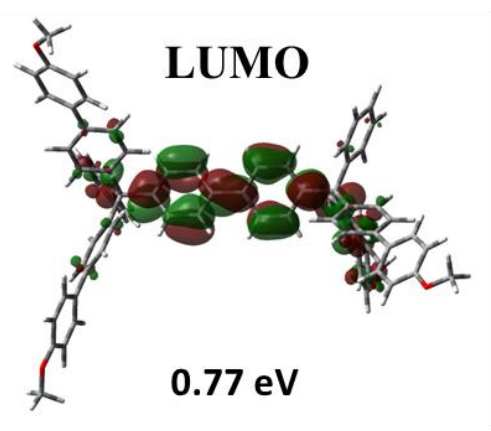
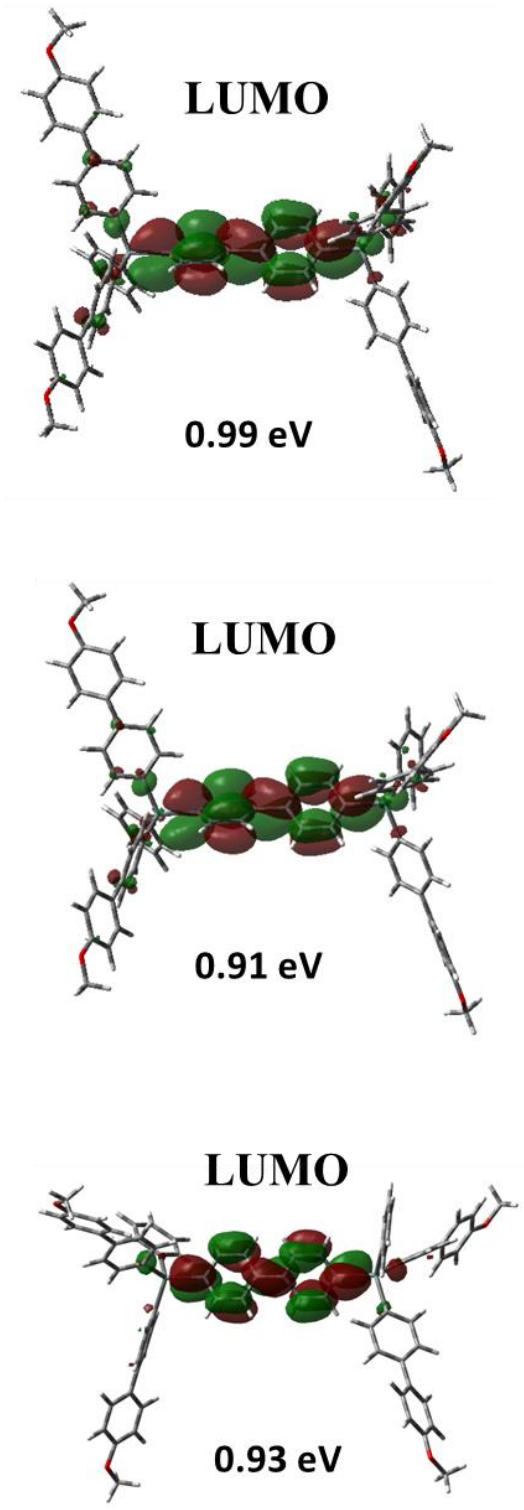
Figure S1. Calculated spatial distributions of HOMO and LUMO for the analogs of polymer backbones. All these repeat unit structures were optimized by the DFT/B3LYP level with the 6-31G (d,p) basis set, only the Sn-based repeat unit with the LANL08d basis set.
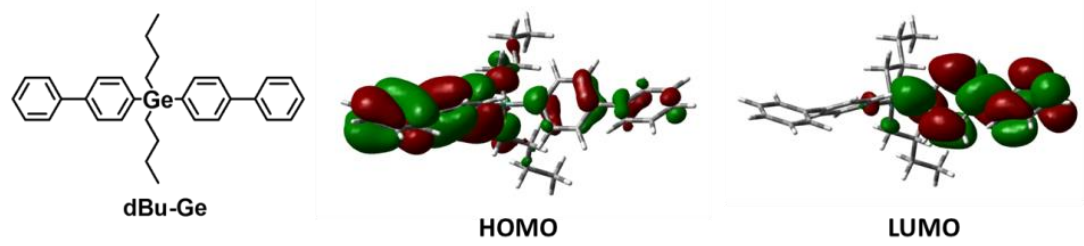

Figure S2. DFT calculation for the unit structure $\mathrm{dBu}-\mathrm{Ge}$, which was optimized by the DFT/B3LYP level with the 6-31G (d,p) basis set.

\section{Photophysical properties}
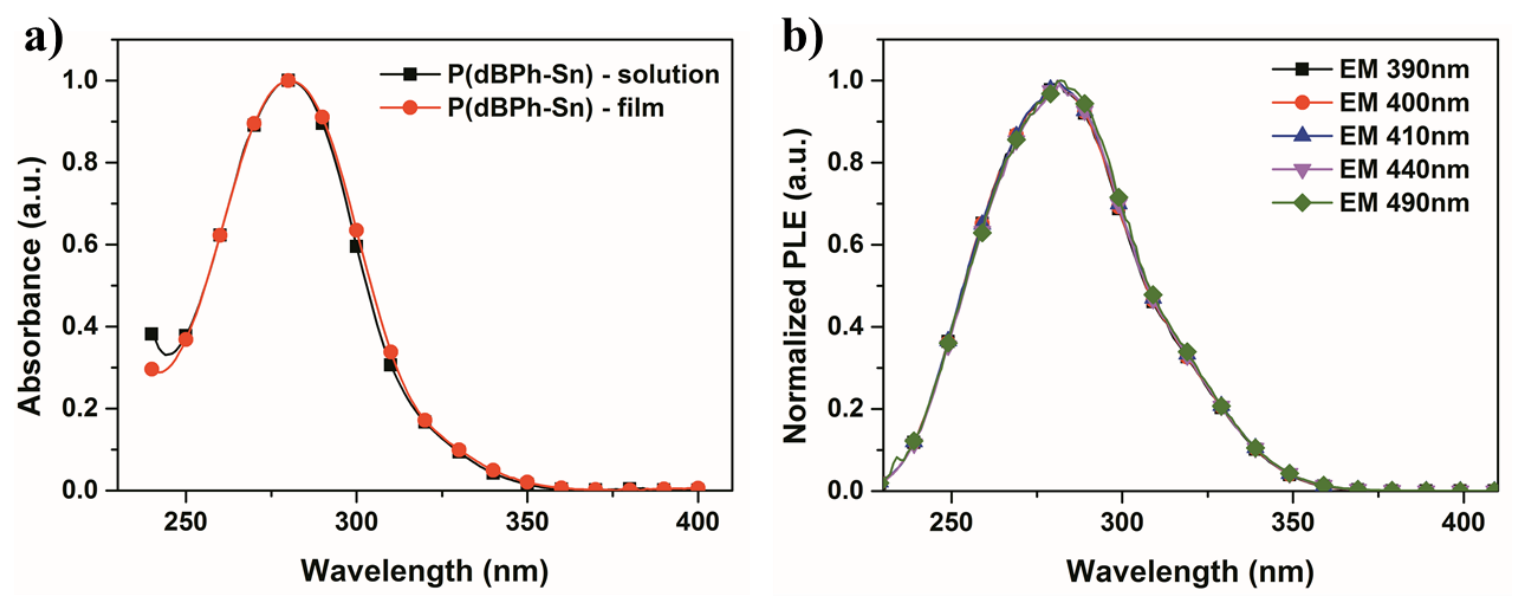

Figure S3. a) UV-vis absorption spectra of $\mathrm{P}(\mathrm{dBPh}-\mathrm{Sn})$ in diluted solution $\left(1 \times 10^{-5} \mathrm{M}\right.$ in $\left.\mathrm{CHCl}_{3}\right)$ and in film, and b) PLE spectra of $\mathrm{P}(\mathrm{dBPh}-\mathrm{Sn})$ film. 


\section{Transient photoluminescence}

The parameters were obtained by exponentially fitting of the decay curves in Figure $4 \mathrm{~b}$ with the following equation:

$$
I_{P L}(\mathrm{t})=A_{1} e^{-t / \tau_{1}}+A_{2} e^{-t / \tau_{2}} \quad(\text { Equation } 1)
$$

Where $I_{\mathrm{PL}}$ is the photoluminescence intensity, $\mathrm{A} 1$ and $\mathrm{A} 2$ are the quantities of emission components, $\mathrm{t}$ is decay time, and $\tau_{1}$ and $\tau_{2}$ are the lifetimes of the corresponding emission components.

Table S1. Fitting parameters of the exciton lifetimes for $12 \mathrm{wt} \%$ FIrpic doped in the polymers and PS.

\begin{tabular}{|c|c|c|c|c|c|c|}
\hline Polymer & $\begin{array}{c}\tau_{1} \\
{[\mathrm{~ns}]}\end{array}$ & $\begin{array}{c}\mathbf{A}_{1} /\left(\mathbf{A}_{1}+\mathbf{A}_{2}\right) \\
{[\% \mathbf{\%}]}\end{array}$ & $\begin{array}{c}\tau_{2} \\
{[\mathrm{~ns}]}\end{array}$ & $\begin{array}{c}\mathbf{A}_{2} /\left(\mathbf{A}_{1}+\mathbf{A}_{2}\right) \\
{[\%]}\end{array}$ & $<\boldsymbol{\tau}>\mathrm{a}$ & $\chi^{2 \mathrm{~b}}$ \\
\hline$P(d B P h-C)+12 w t \%$ FIrpic & 155 & 26.79 & 735 & 73.21 & 580 & 1.46 \\
\hline $\mathrm{P}(\mathrm{dBPh}-\mathrm{Si})+12 \mathrm{wt} \%$ FIrpic & 130 & 14.03 & 951 & 85.97 & 836 & 1.35 \\
\hline $\mathrm{P}(\mathrm{dBPh}-\mathrm{Ge})+12 \mathrm{wt} \%$ FIrpic & 217 & 15.71 & 1017 & 84.29 & 891 & 1.29 \\
\hline P(dBPh-Sn) +12wt\% FIrpic & 112 & 46.90 & 679 & 53.10 & 413 & 1.49 \\
\hline $\begin{array}{c}\text { Polystyrene (PS)+12wt\% } \\
\text { FIrpic }\end{array}$ & 270 & 17.86 & 1030 & 82.14 & 894 & 1.19 \\
\hline
\end{tabular}

${ }^{a}$ Averaged lifetime that was calculated as $\langle\tau\rangle=\sum$ ai $\tau i$, where $\tau_{\mathrm{i}}$ and $\mathrm{a}_{\mathrm{i}}$ are the exciton lifetime and their fractions of $\mathrm{A}_{1}$ and $\mathrm{A}_{2}$, respectively. ${ }^{3} \mathrm{C}$ Chi-spaure value for exponentially fitting of the decay curve. 


\section{Single carrier devices}

The hole-only (ITO/PEDOT:PSS/polymer $\left.(80 \mathrm{~nm}) / \mathrm{MoO}_{3}(10 \mathrm{~nm}) / \mathrm{Al}\right)$ and electron-only (glass/Al (60nm)/Ca (20nm)/polymer $(80 \mathrm{~nm}) / \mathrm{CsF}(1 \mathrm{~nm}) / \mathrm{Al})$ devices were measured for their current density versus applied voltage as shown in Figure S4. By applying the space-charge limited current (SCLC) equation, $J=9 / 8 \varepsilon \varepsilon_{0} \mu \mathrm{V}^{2} \mathrm{~d}^{-3}$ (where $\mathrm{J}$ is the current density, $\mathrm{V}$ the applied voltage, $\mu$ the carrier, $\varepsilon$ the relative vacuum permittivity (about 3 for organic materials), and $\varepsilon_{0}$ the vacuum permittivity), the hole and electron mobilities were determined. ${ }^{4}$

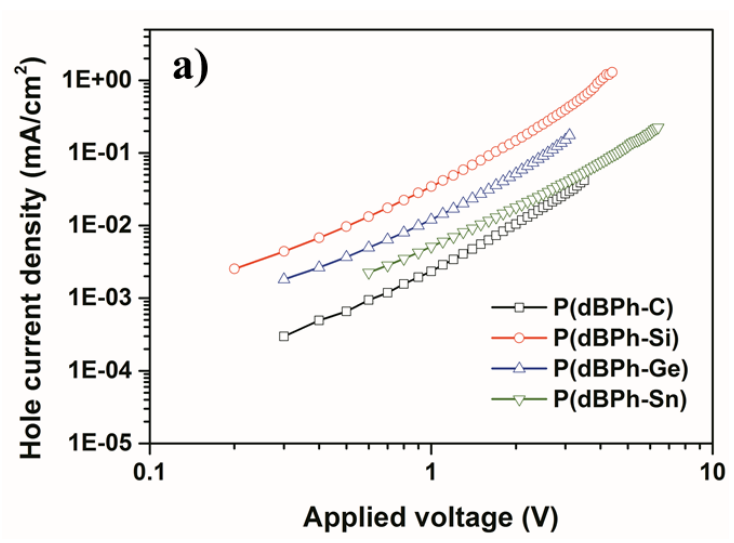

Figure S4. Single carrier devices for polymer/ $\mathrm{MoO}_{3} / \mathrm{Al}$ and (b) electron- only device: glass/Al $/ \mathrm{Ca} /$ polymer/CsF/Al.

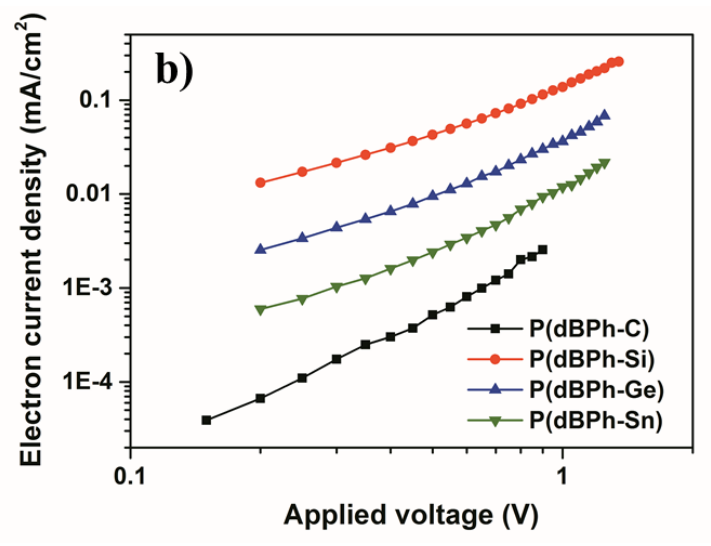

(a) hole-only device: ITO/PEDOT:PSS/ 
The reported data of high performance blue Ph-OLEDs with the difference in $\mathrm{E}_{\mathrm{T}}$ of host to guest

Table S2 Relationship between device performance and difference in $\mathrm{E}_{\mathrm{T}}$ of host and guest for the high peformance blue Ph-OLEDs

\begin{tabular}{|c|c|c|c|c|}
\hline $\begin{array}{c}\text { Host } \\
\text { (Triplet energy) }\end{array}$ & $\begin{array}{c}\text { Emitter } \\
\text { (Triplet energy) }\end{array}$ & $\mathbf{E}_{\mathrm{T}, \text { host }}-\mathbf{E}_{\mathrm{T}, \text { guest }}$ & $\begin{array}{c}\text { Device } \\
\text { performance }\end{array}$ & Ref. \\
\hline $\begin{array}{c}\text { mCP:B3PYMPM } \\
\text { exciplex } \\
\left(\mathrm{E}_{\mathrm{T}}=2.68 \mathrm{eV}\right)\end{array}$ & $\begin{array}{c}\text { FIrpic } \\
\left(\mathrm{E}_{\mathrm{T}}=2.62 \mathrm{eV}\right)\end{array}$ & $0.06 \mathrm{eV}$ & $\begin{array}{c}\mathrm{CE}_{\max }=62.2 \mathrm{~cd} / \mathrm{A} \\
\mathrm{EQE}_{\max }=29.5 \%\end{array}$ & {$[5]$} \\
\hline $\begin{array}{c}\text { mCP:PO-T2T } \\
\text { Exciplex } \\
\left(\mathrm{E}_{\mathrm{T}}=2.64 \mathrm{eV}\right)\end{array}$ & $\begin{array}{c}\text { FIrpic } \\
\left(\mathrm{E}_{\mathrm{T}}=2.63 \mathrm{eV}\right)\end{array}$ & $0.01 \mathrm{eV}$ & $\begin{array}{c}\mathrm{PE}_{\max }=66.01 \mathrm{~m} / \mathrm{W} \\
\mathrm{EQE}_{\max }=30.3 \%\end{array}$ & {$[6]$} \\
\hline $\begin{array}{c}\text { mCBP:PO-T2T } \\
\text { exciplex } \\
\left(E_{\mathrm{T}}=2.63 \mathrm{eV}\right)\end{array}$ & $\begin{array}{c}\text { FIrpic } \\
\left(\mathrm{E}_{\mathrm{T}}=2.62 \mathrm{eV}\right)\end{array}$ & $0.01 \mathrm{eV}$ & $\begin{array}{c}\mathrm{PE}_{\max }=79.61 \mathrm{~m} / \mathrm{W} \\
\mathrm{EQE}_{\max }=34.1 \%\end{array}$ & {$[7]$} \\
\hline $\begin{array}{c}2,6-\mathrm{DCzPPy} \\
\left(\mathrm{E}_{\mathrm{T}}=2.71 \mathrm{eV}\right)\end{array}$ & $\begin{array}{l}\text { Fac-Ir(mpim })_{3} \\
\left(\mathrm{E}_{\mathrm{T}}=2.62 \mathrm{eV}\right)\end{array}$ & $0.09 \mathrm{eV}$ & $\begin{array}{c}\mathrm{CE}_{100}=80.1 \mathrm{~cd} / \mathrm{A} \\
\mathrm{PE}_{100}=86.0 \mathrm{~lm} / \mathrm{W} \\
\mathrm{EQE}_{100}=32.5 \%\end{array}$ & {$[8]$} \\
\hline $\begin{array}{c}\mathrm{CzBPCb} \\
\left(\mathrm{E}_{\mathrm{T}}=2.75 \mathrm{eV}\right)\end{array}$ & $\begin{array}{c}\text { FIrpic } \\
\left(\mathrm{E}_{\mathrm{T}}=2.65 \mathrm{eV}\right)\end{array}$ & $0.10 \mathrm{eV}$ & $\begin{array}{c}\mathrm{CE}_{100}=53.6 \mathrm{~cd} / \mathrm{A} \\
\mathrm{PE}_{100}=50.6 \mathrm{~lm} / \mathrm{W} \\
\mathrm{EQE}_{100}=30.1 \%\end{array}$ & [9] \\
\hline
\end{tabular}




\section{S2. Materials and Methods}
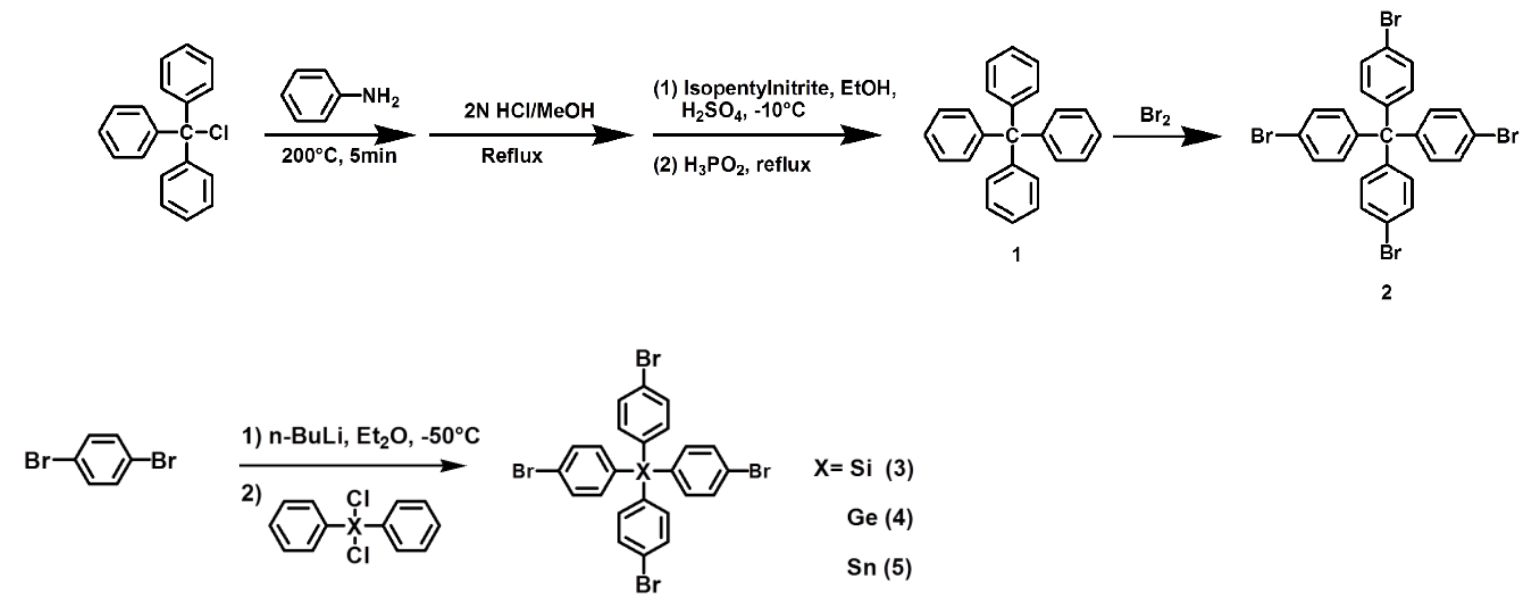

Scheme S1. Synthetic route for compound 2, 3, 4, 5

Tetraphenylmethane (1). ${ }^{10}$

A mixture of triphenylmethyl chloride (19.5 g. $70 \mathrm{mmol})$ and aniline (19.6 g, $210 \mathrm{mmol})$ was heated at $220^{\circ} \mathrm{C}$ for $5 \mathrm{~min}$ and then cooled to $90^{\circ} \mathrm{C}$. Treated with $2 \mathrm{~N} \mathrm{HCl}(110 \mathrm{ml})$ and methanol $(100 \mathrm{ml})$, and the resulting mixture refluxed for $1 \mathrm{~h}$. The reaction mixture was cooled to room temperature and filtered to get a gray solid, which was then dissolved in a mixture of ethanol $(140 \mathrm{ml})$ and concentrated $\mathrm{H}_{2} \mathrm{SO}_{4}(22 \mathrm{ml})$. The resulting mixture was cooled to $-10^{\circ} \mathrm{C}$, stirred, and isopentylnitrite $(14 \mathrm{ml}, 105 \mathrm{mmol})$ was added dropwise into the reaction. The mixture was then stirred for $1 \mathrm{~h}$, treated with $50 \%$ hypophosphorous acid $(50 \mathrm{ml})$, and heated to reflux for $1 \mathrm{~h}$. The reaction mixture was cooled to room temperature and then filtered to provide an olive solid, which was washed with ethanol and dried in vacuum to afford compound $2\left(16.0 \mathrm{~g}, 71 \%\right.$ ) as a pale colored solid. ${ }^{1} \mathrm{HNMR}\left(500 \mathrm{MHz}, \mathrm{CDCl}_{3}\right) . \delta$ (ppm): 7.09-7.03 (m, 20H).

\section{Tetra(p-bromophenyl)methane (2).}

It was prepared according to the procedure reported in the literature. ${ }^{11}$ For compound 2: A pale brown solid (7.94 g, 42\%). ${ }^{1} \mathrm{HNMR}\left(500 \mathrm{MHz}, \mathrm{CDCl}_{3}\right) . \delta(\mathrm{ppm}): 7.38$ (d, J=8.5 Hz, $8 \mathrm{H}), 6.98(\mathrm{~d}, \mathrm{~J}=8.5 \mathrm{~Hz}, 8 \mathrm{H})$.

\section{Tetra(p-bromophenyl)silane (3).}

It was prepared according to the procedure reported in the literature. ${ }^{12}$ For compound 3 : A white solid (18.3 g, 65.0\%). ${ }^{1} \mathrm{HNMR}\left(500 \mathrm{MHz}, \mathrm{CDCl}_{3}\right) . \delta(\mathrm{ppm}): 7.52$ (d, J=7.5 Hz, 8H), $7.32(\mathrm{~d}, \mathrm{~J}=7.5 \mathrm{~Hz}, 8 \mathrm{H})$.

\section{Tetra(p-bromophenyl)germane (4).}


It was prepared according to the same procedure for compound 3. For compound 4: A white solid (10.5 g, $42 \%$ ). ${ }^{1} \mathrm{HNMR}\left(500 \mathrm{MHz}, \mathrm{CDCl}_{3}\right) . \delta(\mathrm{ppm}): 7.51$ (d, J=8.5 Hz, 8H), $7.28(\mathrm{~d}, \mathrm{~J}=8.5 \mathrm{~Hz}, 8 \mathrm{H})$.

\section{Tetra(p-bromophenyl)stannane (5).}

It was prepared according to the same procedure of compound 3. For compound 5: A white solid (8.4 g, $38 \%$ ). ${ }^{1} \mathrm{HNMR}\left(500 \mathrm{MHz}, \mathrm{CDCl}_{3}\right) . \delta$ (ppm): 7.53 (d, J=8.0 Hz, 8H), 7.35 $(\mathrm{d}, \mathrm{J}=8.0 \mathrm{~Hz}, 8 \mathrm{H})$.

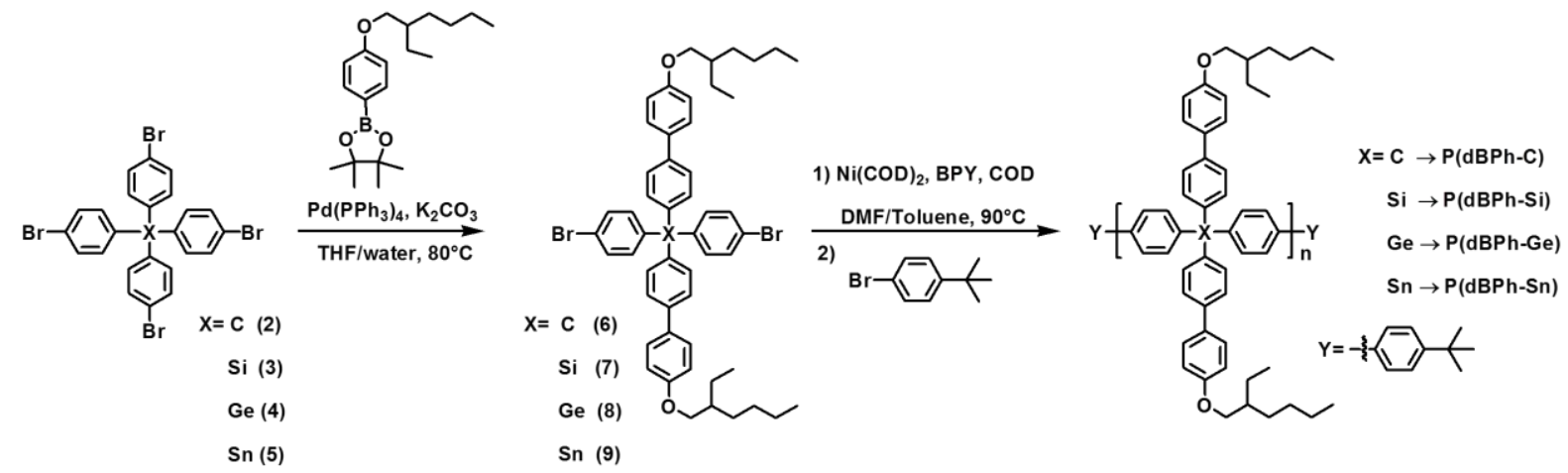

Scheme S2. Synthetic route for $\mathrm{P}(\mathrm{dBPh}-\mathrm{C}), \mathrm{P}(\mathrm{dBPh}-\mathrm{Si}), \mathrm{P}(\mathrm{dBPh}-\mathrm{Ge})$ and $\mathrm{P}(\mathrm{dBPh}-\mathrm{Sn})$.

\section{Bis(4-bromophenyl)-di(p-(2-ethylhexyloxy)diphenyl)methane 6.}

The mixture of tetra( $p$-bromophenyl)methane 2 (3.2 g, $5 \mathrm{mmol}), 2$-(4-(2-ethylhexyloxy) phenyl)-4,4,5,5- tetramethyl-1,3,2- dioxaborolane ${ }^{13}$ (4.2 g, $\left.12.5 \mathrm{mmol}\right), \mathrm{Pd}\left(\mathrm{PPh}_{3}\right)_{4}$ (289 mg, $0.25 \mathrm{mmol}$ ) was dissolved in $60 \mathrm{ml} \mathrm{THF}$, following the addition of $2 \mathrm{M} \mathrm{K}_{2} \mathrm{CO}_{3}$ aqueous solution $(20 \mathrm{ml})$. The solution was degassed with nitrogen for $0.5 \mathrm{~h}$ and then stirring for $12 \mathrm{~h}$ at reflux temperature. The reaction mixture was extracted with ethyl acetate and washed with water, and the organic layer was dried over anhydrous $\mathrm{MgSO}_{(\mathrm{s})}$, filtered and concentrated under vacuum. The residue was purified by silica gel column chromatography using n-hexane/ $\mathrm{CH}_{2} \mathrm{Cl}_{2}=10$ : 1 as eluent to obtain the clear sticky compound 6 (1.94 g, $26 \%$ ). ${ }^{1} \mathrm{HNMR}\left(500 \mathrm{MHz}, \mathrm{CDCl}_{3}\right.$ ). $\delta$ (ppm): 7.48 (d, J=8.5 Hz, 4H), 7.44 (d, J=8.5 Hz, 4H), 7.38 (d, $\mathrm{J}=8.5 \mathrm{~Hz}, 4 \mathrm{H}), 7.20(\mathrm{~d}, \mathrm{~J}=8.5 \mathrm{~Hz}, 4 \mathrm{H}), 7.12(\mathrm{~d}, \mathrm{~J}=8.5 \mathrm{~Hz}, 4 \mathrm{H}), 6.93(\mathrm{~d}, \mathrm{~J}=8.5 \mathrm{~Hz}, 4 \mathrm{H}), 3.85$ $(\mathrm{d}, \mathrm{J}=4.5 \mathrm{~Hz}, 4 \mathrm{H}), 1.75(\mathrm{~m}, 2 \mathrm{H}), 1.47(\mathrm{~m}, 8 \mathrm{H}), 1.31(\mathrm{~m}, 8 \mathrm{H}), 0.92(\mathrm{~m}, 12 \mathrm{H})$.

\section{Bis(4-bromophenyl)-di(p-(2-ethylhexyloxy)diphenyl)silane 7.}

The mixture of tetra(p-bromophenyl)silane (6.52 g, $10 \mathrm{mmol}), 2$-(4-(2-ethylhexyloxy) phenyl)-4,4,5,5- tetramethyl-1,3,2- dioxaborolane (8.4 g, $25 \mathrm{mmol}), \mathrm{Pd}\left(\mathrm{PPh}_{3}\right)_{4}(578 \mathrm{mg}, 0.5$ mmol) was dissolved in $50 \mathrm{ml}$ toluene, following the addition of $2 \mathrm{M} \mathrm{K}_{2} \mathrm{CO}_{3}$ aqueous solution $(50 \mathrm{ml})$. The solution was degassed with nitrogen for $0.5 \mathrm{~h}$ and then stirring for $12 \mathrm{~h}$ at reflux 
temperature. The reaction mixture was extracted with ethyl acetate and washed with water, and the organic layer was dried over anhydrous $\mathrm{MgSO}_{4(\mathrm{~s})}$, filtered and concentrated under vacuum. The residue was purified by silica gel column chromatography using n-hexane/ $\mathrm{CH}_{2} \mathrm{Cl}_{2}=10$ : 1 as eluent to obtain the clear sticky compound 7 (1.58 g, $\left.18 \%\right)$. ${ }^{1} \mathrm{HNMR}$ (500 $\mathrm{MHz}_{\mathrm{CDCl}}$ ). $\delta(\mathrm{ppm}): 7.57(\mathrm{~m}, 8 \mathrm{H}), 7.52(\mathrm{~d}, \mathrm{~J}=8.0 \mathrm{~Hz}, 8 \mathrm{H}), 7.43(\mathrm{~d}, \mathrm{~J}=8.0 \mathrm{~Hz}, 4 \mathrm{H}), 6.96$ (d, $\mathrm{J}=8.5 \mathrm{~Hz}, 4 \mathrm{H}), 3.87(\mathrm{~d}, \mathrm{~J}=4.0 \mathrm{~Hz}, 4 \mathrm{H}), 1.75(\mathrm{~m}, 2 \mathrm{H}), 1.46(\mathrm{~m}, 8 \mathrm{H}), 1.32(\mathrm{~m}, 8 \mathrm{H}), 0.92(\mathrm{~m}$, $12 \mathrm{H})$.

\section{Bis(4-bromophenyl)-di(p-(2-ethylhexyloxy)diphenyl)germane 8.}

It was prepared with the same procedure for compound 7 but tetra( $p$-bromophenyl)germane 4 was used as the starting material. For compound 8: A clear sticky product (1.94 g, $26 \%$ ). ${ }^{1} \mathrm{HNMR}\left(500 \mathrm{MHz}, \mathrm{CDCl}_{3}\right) . \delta(\mathrm{ppm}): 7.58(\mathrm{~d}, \mathrm{~J}=8.0 \mathrm{~Hz}, 4 \mathrm{H})$, $7.53(\mathrm{~m}, 12 \mathrm{H}), 7.41(\mathrm{~d}, \mathrm{~J}=8.0 \mathrm{~Hz}, 4 \mathrm{H}), 6.98(\mathrm{~d}, \mathrm{~J}=9 \mathrm{~Hz}, 4 \mathrm{H}), 3.88(\mathrm{~d}, \mathrm{~J}=4.5 \mathrm{~Hz}, 4 \mathrm{H}), 1.76$ (m, $2 \mathrm{H}), 1.48(\mathrm{~m}, 8 \mathrm{H}), 1.33(\mathrm{~m}, 8 \mathrm{H}), 0.93(\mathrm{~m}, 12 \mathrm{H})$.

\section{Bis(4-bromophenyl)-di(p-(2-ethylhexyloxy)diphenyl)stannane 9.}

It was prepared with the same procedure for compound 7 but tetra( $p$-bromophenyl)stannane $\mathbf{5}$ was used as the starting material. For compound 9: A clear sticky product (0.93 g, $12 \%) .{ }^{1} \mathrm{HNMR}\left(500 \mathrm{MHz}, \mathrm{CDCl}_{3}\right) . \delta(\mathrm{ppm}): 7.60(\mathrm{~m}, 8 \mathrm{H}), 7.53(\mathrm{~m}$, $8 \mathrm{H}), 7.47(\mathrm{~d}, \mathrm{~J}=8 \mathrm{~Hz}, 4 \mathrm{H}), 6.97$ (d, J=9.0 Hz, 4H), $1.76(\mathrm{~m}, 2 \mathrm{H}), 1.47$ (m, 8H), 1.33 (m, 8H), $0.93(\mathrm{~m}, 12 \mathrm{H})$.

\section{General polymerization procedure for these polymers: $\mathrm{P}(\mathrm{dBPh}-\mathrm{C}), \mathrm{P}(\mathrm{dBPh}-\mathrm{Si})$, $P(d B P h-G e)$ and P(dBPh-Sn).}

The monomer (0.6 mmol), bis(1,5-cyclooctadiene) nickel (0) (Ni(COD) $)$ (363 mg, 1.32 mmol), 2,2-bipyridyl (BPY) (206 mg, $1.32 \mathrm{mmol}$ ), 1,5-cyclooctadiene (COD) (143 mg, 1.32 mmol), anhydrous DMF (3 $\mathrm{mL})$ and anhydrous toluene $(3 \mathrm{~mL})$ were added into a reactor under nitrogen atmosphere. The polymerization proceeded at $80^{\circ} \mathrm{C}$ for 4 days, and then 1-bromo-4-tert-butylbenzene as end-capping agent $(0.020 \mathrm{~mL}, 0.12 \mathrm{mmol})$ was added to the reaction mixture and continually reacted for additional $24 \mathrm{~h}$. The resulting polymer was poured into methanol, and stirred for $30 \mathrm{~min}$. The precipitate was collected by filtration and dried and then dissolved in $\mathrm{CHCl}_{3}$. The organic layer was washed with water, dried over anhydrous $\mathrm{MgSO}_{4}$, and evaporated under reduced pressure. The material was re-dissolved in $\mathrm{CHCl}_{3}$, and precipitated in methanol. The precipitate was collected by filtration and dried under high vacuum. The solid was further purified by sequential Soxhlet extraction with methanol, acetone and hexane. After that, the solid was re-dissolved in $\mathrm{CHCl}_{3}$ and then precipitated in methanol. Finally, the solid product was collected and dried under vacuum. 
P(dBPh-C): white solid. GPC analysis showed its weight-average molecular weight $(M w)$ and polydispersity of $19,000 \mathrm{Da}$ and 2.06 , respectively, relative to polystyrene standards. ${ }^{1} \mathrm{HNMR}\left(500 \mathrm{MHz}, \mathrm{CDCl}_{3}\right) . \delta(\mathrm{ppm}): 7.50(12 \mathrm{H}), 7.35(8 \mathrm{H}), 6.94(4 \mathrm{H}), 3.85(4 \mathrm{H}), 1.72(2 \mathrm{H})$, $1.40(8 \mathrm{H}), 1.30(8 \mathrm{H}), 0.90(12 \mathrm{H})$.

P(dBPh-Si): white solid. GPC analysis showed its $M w$ and polydispersity of 63,000 Da and 2.55 , respectively, relative to polystyrene standards. ${ }^{1} \mathrm{HNMR}\left(500 \mathrm{MHz}, \mathrm{CDCl}_{3}\right) . \delta$ (ppm): $7.67(12 \mathrm{H}), 7.55(8 \mathrm{H}), 6.94(4 \mathrm{H}), 3.84(4 \mathrm{H}), 1.71(2 \mathrm{H}), 1.40(8 \mathrm{H}), 1.30(8 \mathrm{H}), 0.90(12 \mathrm{H})$.

P(dBPh-Ge): white solid. GPC analysis showed its $M w$ and polydispersity of 110,000 Da and 2.59 , respectively, relative to polystyrene standards. ${ }^{1} \mathrm{HNMR}\left(500 \mathrm{MHz}, \mathrm{CDCl}_{3}\right) . \delta$ (ppm): 7.70-7.51 (20H), $6.94(4 \mathrm{H}), 3.84(4 \mathrm{H}), 1.72(2 \mathrm{H}), 1.42(8 \mathrm{H}), 1.30(8 \mathrm{H}), 0.90(12 \mathrm{H})$.

P(dBPh-Sn): white solid. GPC analysis showed its $M w$ and polydispersity of 430,000 Da and 7.81, respectively, relative to polystyrene standards. ${ }^{1} \mathrm{HNMR}\left(500 \mathrm{MHz}, \mathrm{CDCl}_{3}\right) . \delta(\mathrm{ppm})$ : 7.74-7.45 (20H), $6.96(4 \mathrm{H}), 3.86(4 \mathrm{H}), 1.72(2 \mathrm{H}), 1.41(8 \mathrm{H}), 1.31(8 \mathrm{H}), 0.91(12 \mathrm{H})$.

\section{References}

(1) Su, S.-J.; Chiba, T.; Takeda, T.; Kido, J. Pyridine-Containing Triphenylbenzene Derivatives with High Electron Mobility for Highly Efficient Phosphorescent OLEDs. Adv. Mater. 2008, 20 (11), 2125-2130

(2) Leeuw, D. M. d.; Simenon, M. M. J.; Brown, A. R.; Einerhand, R. E. F. Stability of N-Type Doped Conducting Polymers and Consequences for Polymeric Microelectronic Devices. Synth. Met. 1997, 87, 53-59

(3) Tamai, Y.; Ohkita, H.; Benten, H.; Ito, S. Triplet Exciton Dynamics in Fluorene-Amine Copolymer Films. Chem. Mater. 2014, 26 (8), 2733-2742 
(4) Murgatroyd, P. N. Theory of Space-Charge-Limited Current Enhanced by Frenkel Effect. J. Phys. D: Appl. Phys. 1970, 3, 151-156

(5) Shin, H.; Lee, S.; Kim, K. H.; Moon, C. K.; Yoo, S. J.; Lee, J. H.; Kim, J. J. Blue phosphorescent organic light-emitting diodes using an exciplex forming co-host with the external quantum efficiency of theoretical limit. Adv. Mater. 2014, 26 (27), 4730-4734

(6) Lee, J.-H.; Cheng, S.-H.; Yoo, S.-J.; Shin, H.; Chang, J.-H.; Wu, C.-I.; Wong, K.-T.; Kim, J.-J. An Exciplex Forming Host for Highly Efficient Blue Organic Light Emitting Diodes with Low Driving Voltage. Adv. Funct. Mater. 2015, 25 (3), 361-366

(7) Shin, H.; Lee, J. H.; Moon, C. K.; Huh, J. S.; Sim, B.; Kim, J. J. Sky-Blue Phosphorescent OLEDs with 34.1\% External Quantum Efficiency Using a Low Refractive Index Electron Transporting Layer. Adv. Mater. 2016, 28 (24), 4920-4925

(8) Udagawa, K.; Sasabe, H.; Igarashi, F.; Kido, J. Simultaneous Realization of High EQE of 30\%, Low Drive Voltage, and Low Efficiency Roll-Off at High Brightness in Blue Phosphorescent OLEDs. Advanced Optical Materials 2016, 4 (1), 86-90

(9) Lee, C. W.; Lee, J. Y. Above 30\% external quantum efficiency in blue phosphorescent organic light-emitting diodes using pyrido[2,3-b]indole derivatives as host materials. Adv.

Mater. 2013, 25 (38), 5450-5454

(10) Su, D.; Menger, F. M. Tetrastyrylmethane. Tetrahedron Lett. 1997, 38, 1485-1488 
(11) Ng, M. C.; Craig, D. J.; Harper, J. B.; van-Eijck, L.; Stride, J. A. The Central Atom Size Effect on the Structure of Group 14 Tetratolyls. Chemistry 2009, 15 (27), 6569-6572

(12) Zhang, B.; Wang, Z. Building Ultramicropores within Organic Polymers Based on a Thermosetting Cyanate Ester Resin. Chem. Commun. 2009, (33), 5027-5029

(13) Choi, I. T.; Ju, M. J.; Song, S. H.; Kim, S. G.; Cho, D. W.; Im, C.; Kim, H. K. Tailor-Made Hole-Conducting Coadsorbents for Highly Efficient Organic Dye-Sensitized Solar Cells. Chemistry 2013, 19 (46), 15545-15555 